\title{
Improvement of Pitting Corrosion Resistance of Type 316L Stainless Steel by Potentiostatic Removal of Surface MnS Inclusions
}

\author{
Nobuyoshi Hara, ${ }^{1}$ Koichi Hirabayashi, ${ }^{2,3}$ Yu Sugawara, ${ }^{1}$ and Izumi Muto ${ }^{1}$ \\ ${ }^{1}$ Department of Materials Science, Graduate School of Engineering, Tohoku University, 6-6-02 Aobayama, \\ Aoba-ku, Sendai 980-8579, Japan \\ ${ }^{2}$ Department of Materials Science and Engineering, School of Engineering, Tohoku University, 6-6-02 Aobayama, \\ Aoba-ku, Sendai 980-8579, Japan \\ ${ }^{3}$ ISFnetlife Ltd., Akasaka 7-1-16, Minato-ku, Tokyo 107-0052, Japan
}

Correspondence should be addressed to Nobuyoshi Hara, haran@material.tohoku.ac.jp

Received 26 March 2012; Accepted 15 May 2012

Academic Editor: Rokuro Nishimura

Copyright (C) 2012 Nobuyoshi Hara et al. This is an open access article distributed under the Creative Commons Attribution License, which permits unrestricted use, distribution, and reproduction in any medium, provided the original work is properly cited.

\begin{abstract}
The beneficial effect of the removal of MnS inclusions on the pitting of stainless steels has been demonstrated in two ways. (1) High-purity Type 316L stainless steel with no inclusions was used as a specimen in the measurement of anodic polarization curves in $0.5 \mathrm{M} \mathrm{NaCl}$ and (2) commercial Type $316 \mathrm{~L}$ stainless steel with $\mathrm{MnS}$ and slag-related inclusions was first polarized at different potentials for $30 \mathrm{~min}$ in $1 \mathrm{M} \mathrm{Na}_{2} \mathrm{SO}_{4}$ of $\mathrm{pH} 3$ and then anodic polarization measurements were taken in $0.5 \mathrm{M} \mathrm{NaCl}$. Pitting did not occur in the passive or transpassive region of the high-purity steel. The polarization treatment dissolved MnS and some oxide inclusions $\left(\mathrm{CaO}\right.$ and $\left.\mathrm{SiO}_{2}\right)$ on the surface of the commercial steel. An increase in pitting potential of the commercial steel was noted after treatment at potentials above $0.2 \mathrm{~V}$. At the same time, the number of current spikes due to metastable pits decreased significantly. These results are more likely due to the beneficial effect of removing MnS inclusions from the steel surface rather than the modification effect of the chemical composition of passive films on the surface.
\end{abstract}

\section{Introduction}

Manganese sulfide $(\mathrm{MnS})$ inclusions are known to act as the initiation sites of pitting corrosion on stainless steels [1-9], while the overall dissolution of the inclusions is not necessary for the formation of pit initiation sites [10-17]. It is therefore expected that the removal of surface MnS inclusions improves the pitting corrosion resistance of stainless steels. The aim of treating the surface of stainless steels with processes like nitric acid passivation (ASTM A380 and ASTM A967) is to form a stable Cr-enriched passive oxide film [18], which plays an important role in providing high corrosion resistance to stainless steels. Such surface treatment has an additional effect of dissolving and removing the MnS inclusions from the surface of stainless steels [19]. Therefore, the improvement of pitting corrosion resistance by passivation treatments can be attributed not only to the modification of the chemical composition of the passive films but also to the removal of MnS from the surface of stainless steels. However, these two effects cannot be distinguished from each other in practice. For the further development of passivation treatments of stainless steels which meet environmental regulations and human safety standards, it is important to understand the intrinsic mechanism of each effect provided by passivation treatments.

The purpose of the present study is to examine solely the effect of removing $\mathrm{MnS}$ on the pitting corrosion resistance of austenitic stainless steels. To realize this purpose, surface $\mathrm{MnS}$ inclusions were removed by potentiostatic anodic polarization in a weakly acidic $\mathrm{Na}_{2} \mathrm{SO}_{4}$ solution and the pitting corrosion resistance was then examined by potentiodynamic polarization in a neutral $\mathrm{NaCl}$ solution. 
TABle 1: Chemical composition of specimens (wt $\%$ ).

\begin{tabular}{lccccccccc}
\hline Specimen & $\mathrm{C}$ & $\mathrm{Si}$ & $\mathrm{Mn}$ & $\mathrm{P}$ & $\mathrm{S}$ & $\mathrm{Ni}$ & $\mathrm{Cr}$ & $\mathrm{Mo}$ & $\mathrm{Cu}$ \\
\hline Commercial type 316L & 0.022 & 0.69 & 0.9 & 0.027 & 0.004 & 12.08 & 17.25 & 2.09 & - \\
High-purity type 316L & 0.004 & 0.01 & 0.01 & 0.003 & 0.001 & 14.78 & 17.4 & 2.63 & 0.01 \\
\hline
\end{tabular}

\section{Experimental}

Commercial Type 316L and high-purity Type 316L stainless steels were used as specimens. The chemical composition of the steels is given in Table 1. The high-purity Type $316 \mathrm{~L}$ steel was prepared by a vacuum induction melting method using electrolytic $\mathrm{Fe}, \mathrm{Cr}$, and $\mathrm{Ni}$ and high-purity $\mathrm{Mo}$ as starting materials. Plates with dimensions of $15 \times 25 \times 2 \mathrm{~mm}$ were cut from cold rolled sheets and heat-treated at $1323 \mathrm{~K}$ for $0.5 \mathrm{~h}$ followed by water quenching. The specimens were mechanically ground with $\mathrm{SiC}$ paper through a 1500 grid and cleaned ultrasonically with acetone. The specimen surfaces, except for the electrode area of $10 \times 10 \mathrm{~mm}$, were covered with epoxy resin and subsequently with paraffin.

To evaluate the pitting corrosion resistance, potentiodynamic polarization measurements were carried out with a conventional three-electrode cell. The electrolyte solution was $0.5 \mathrm{M} \mathrm{NaCl}$ at $298 \mathrm{~K}$. The solution was deaerated with purified $\mathrm{N}_{2}$ for more than 30 min before the measurements. The potential scan rate was $3.8 \times 10^{-4} \mathrm{~V} \mathrm{~s}^{-1}\left(23 \mathrm{mV} \mathrm{min}{ }^{-1}\right)$. The polarization was started from $50 \mathrm{mV}$ lower than the open-circuit potential after immersion in the test solution for $10 \mathrm{~min}$. The reference electrode was an $\mathrm{Ag} / \mathrm{AgCl}$ (3.33 M $\mathrm{KCl})$ electrode. All the potentials cited in this paper refer to this electrode.

In order to remove MnS inclusions from the surface of specimens, potentiostatic polarization treatment was performed at different potentials of 0.1 to $0.5 \mathrm{~V}$ for $30 \mathrm{~min}$ in $1 \mathrm{M} \mathrm{Na}_{2} \mathrm{SO}_{4}$ of $\mathrm{pH} 3$. The solution $\mathrm{pH}$ was adjusted with the addition of a small amount of $1 \mathrm{M} \mathrm{H}_{2} \mathrm{SO}_{4}$. Immediately after potentiostatic polarization treatment, the potentiodynamic anodic polarization curves in $0.5 \mathrm{M} \mathrm{NaCl}$ were measured in the manner described above.

A JEOL JSM-6510 scanning electron microscope (SEM) equipped with a JEOL JED-2300 energy dispersive X-ray spectrometer (EDS) was employed to analyze the inclusions on the surface of the specimens. The accelerating voltage was set at $20 \mathrm{kV}$. The specimens used for the SEM/EDS analysis were first mirror polished with a diamond paste of $1 \mu \mathrm{m}$.

\section{Results and Discussion}

Figure 1 shows the anodic polarization curves of as-polished commercial Type 316L and high-purity Type 316L stainless steels in $0.5 \mathrm{M} \mathrm{NaCl}$. The commercial steel exhibits many current spikes in the potential range from $0.2 \mathrm{~V}$ to $0.6 \mathrm{~V}$ and a sharp increase in current at around $0.6 \mathrm{~V}$. These two characteristic events can be attributed to the formation of metastable pits and the growth of a stable pit, respectively. In the polarization curve of the high-purity steel, no characteristic pitting event was observed in the passivity and transpassivity region from $0.0 \mathrm{~V}$ to $1.2 \mathrm{~V}$. No pit

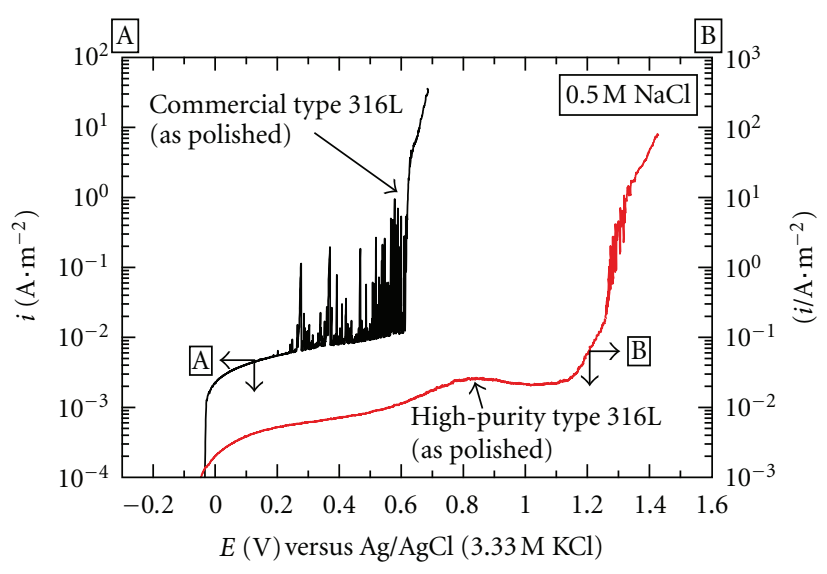

Figure 1: Anodic polarization curves of commercial Type 316L and high-purity Type 316L stainless steels in $0.5 \mathrm{M} \mathrm{NaCl}$.

initiation sites were found on the surface of the high-purity steel.

Round inclusions with a diameter of 5 to $10 \mu \mathrm{m}$ were observed on the surface of as-polished commercial Type 316L stainless steel. Figure 2 shows the SEM image and EDS elemental maps of a typical inclusion in the commercial steel. A skin of steel partly covers the central part of the inclusion. The inclusion consists mainly of oxides, $\mathrm{CaO}, \mathrm{SiO}_{2}, \mathrm{Al}_{2} \mathrm{O}_{3}$, and $\mathrm{MgO}$, which come from steel making slag. Small MnS particles are distributed in the peripheral region of the oxide inclusion. Because a skin of steel partly covers the inclusion, MnS particles observed in the central part of the inclusion are actually not inside but outside the oxide inclusion. The dissolution of $\mathrm{MnS}$ at the boundary region between the inclusion and the steel matrix is thought to have triggered the pitting observed in Figure 1. No visible inclusion was detected on the surface of the high-purity steel.

The results of the previous study using a microelectrochemical technique suggest that $\mathrm{MnS}$ inclusions undergo electrochemical dissolution under anodic polarization in neutral solutions [10-17]. Figure 3 shows the SEM image and EDS elementary maps of commercial Type 316L stainless steel after potentiostatic polarization at $0.5 \mathrm{~V}$ for $30 \mathrm{~min}$ in $1 \mathrm{M} \mathrm{Na} \mathrm{SO}_{4}$ with $\mathrm{pH}$ 3. This SEM/EDS analysis was performed in the same region as the images in Figure 2. Not only $\mathrm{MnS}$ but also $\mathrm{CaO}$ and $\mathrm{SiO}_{2}$ components were dissolved by the polarization treatment. Spinel $\left(\mathrm{MgAl}_{2} \mathrm{O}_{3}\right)$ and perovskite $\left(\mathrm{CaTiO}_{3}\right)$ remained undissolved after polarization treatment. According to the potential-pH diagram of $\mathrm{MnS}-\mathrm{H}_{2} \mathrm{O}$ system [20], the stable $\mathrm{Mn}$ and $\mathrm{S}$ species in the potential range of $0.1 \mathrm{~V}$ to $0.5 \mathrm{~V}$ at $\mathrm{pH} 3$ were $\mathrm{Mn}^{2+}$ and $\mathrm{S}_{2} \mathrm{O}_{3}{ }^{2-}$ ions, respectively. Therefore, $\mathrm{MnS}$ undergoes 

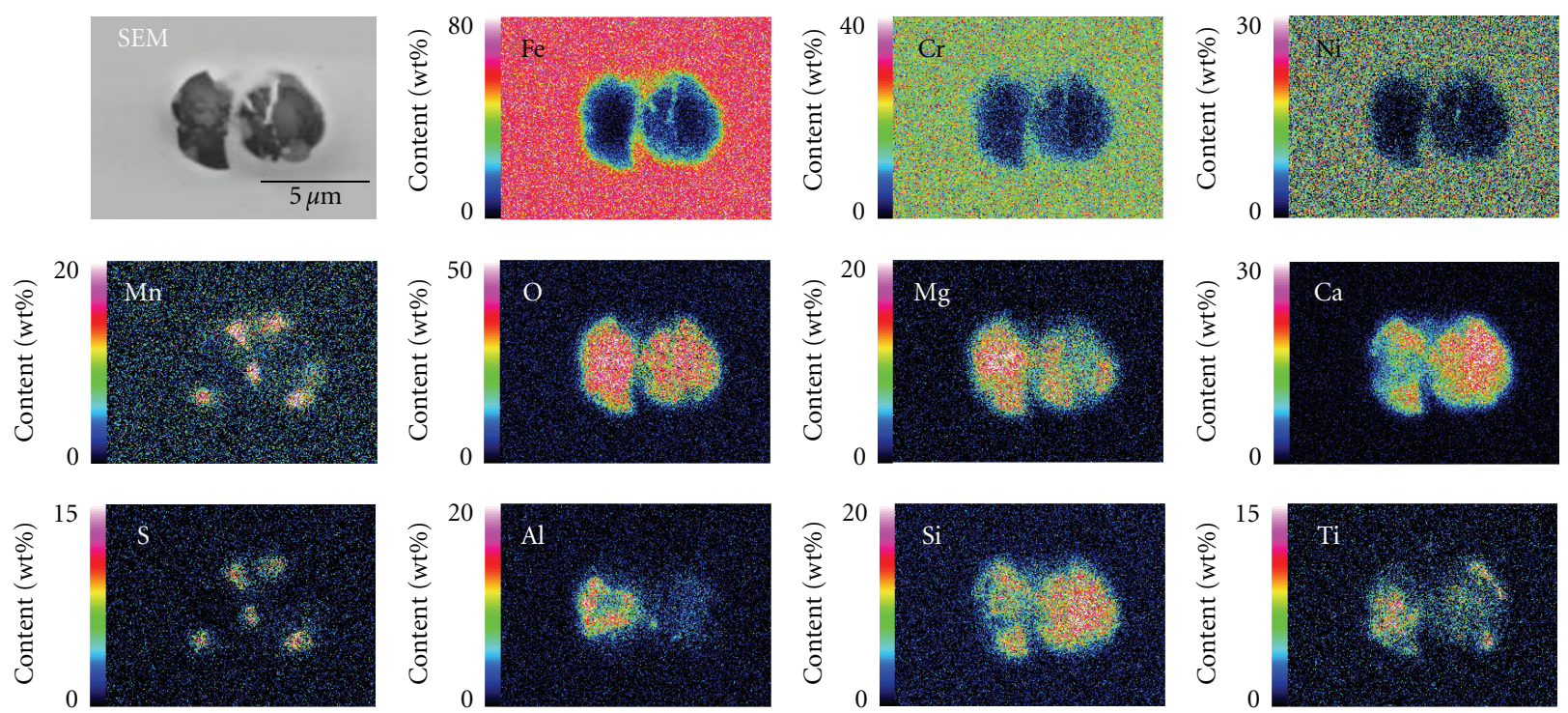

FIGURE 2: SEM image and EDS elemental mappings for as-polished commercial Type 316L stainless steel.
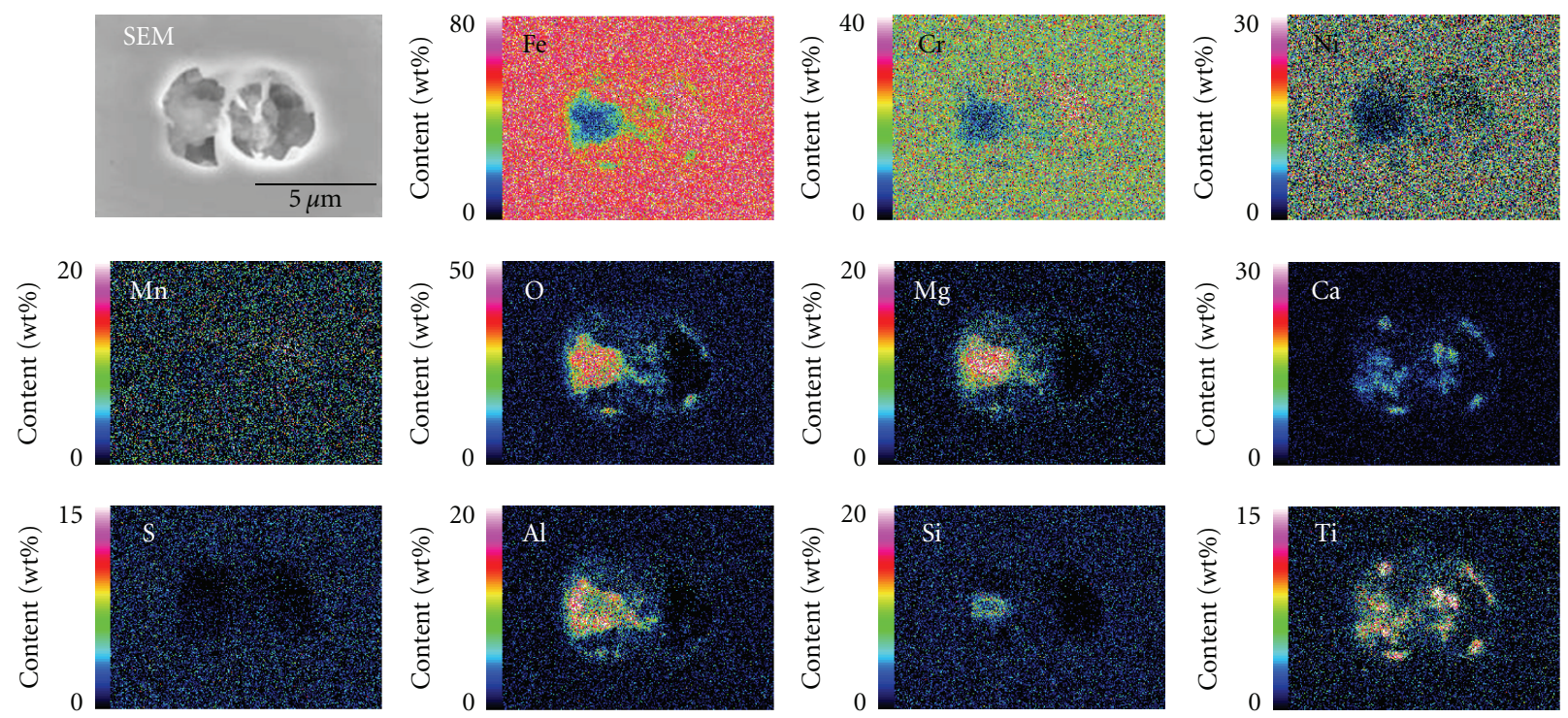

FIGURE 3: SEM image and EDS elemental mappings for the same region as in Figure 2 after polarization treatment at $0.5 \mathrm{~V}$ for $30 \mathrm{~min}$ in $1 \mathrm{M}$ $\mathrm{Na}_{2} \mathrm{SO}_{4}$ of $\mathrm{pH} 3$.

the following oxidative dissolution during the polarization treatments:

$$
2 \mathrm{MnS}+3 \mathrm{H}_{2} \mathrm{O} \longrightarrow 2 \mathrm{Mn}^{2+}+\mathrm{S}_{2} \mathrm{O}_{3}{ }^{2-}+6 \mathrm{H}^{+}+8 e^{-}
$$

The dissolution of $\mathrm{CaO}$ and $\mathrm{SiO}_{2}$ is caused by chemical reactions. Since $\mathrm{SiO}_{2}$ itself is insoluble in weakly acidic solutions, the disappearance of $\mathrm{SiO}_{2}$ after the treatments reveals that $\mathrm{SiO}_{2}$ forms soluble calcium silicate such as $2 \mathrm{CaO} \bullet \mathrm{SiO}_{2}$ and $3 \mathrm{CaO} \cdot \mathrm{SiO}_{2}$ in the inclusion.

The effect of potentiostatic polarization treatments on the pitting corrosion resistance of commercial 316L stainless steel was examined by measuring the anodic polarization curves in $0.5 \mathrm{M} \mathrm{NaCl}$. Figure 4 exhibits three anodic polarization curves after the same polarization treatment at $0.5 \mathrm{~V}$ for $30 \mathrm{~min}$ in $1 \mathrm{M} \mathrm{Na}_{2} \mathrm{SO}_{4}$. Compared with the as-polished specimen shown in Figure 1, fewer current spikes due to metastable pitting were noted and the onset potential of stable pitting was higher. However, the characteristics of the parameters of pitting varied from experiment to experiment, as can be seen in Figure 4. This indicates that the pitting had a randomness or a probabilistic property [21-23]. In order to statistically treat the pitting properties, we repeated the anodic polarization measurement at least eight times for each treatment condition. The following three electrochemical parameters were evaluated from each of the polarization curves: the onset potential of metastable pitting, $E_{\mathrm{r}}$, the onset potential of stable pitting, $E_{\mathrm{pit}}$, and the number of metastable pits, $N_{\text {msp }}$, which is assumed to be equal to the number of 


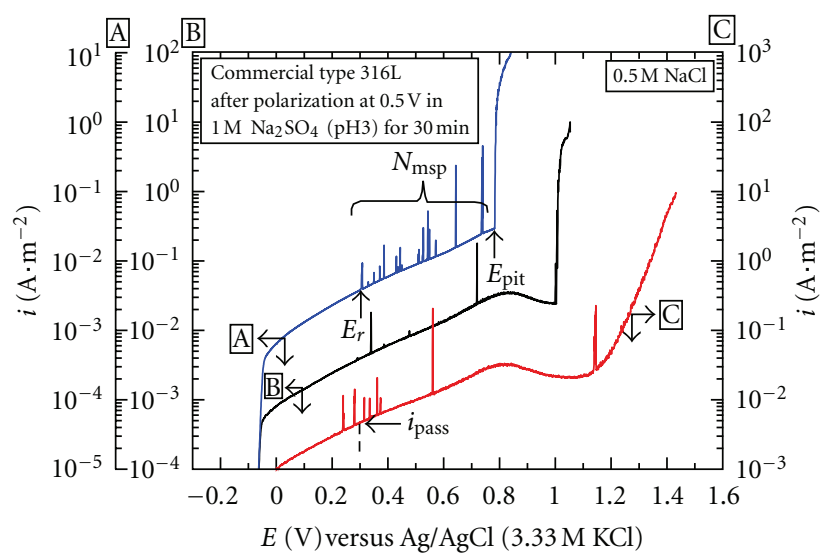

Figure 4: Anodic polarization curves of commercial Type 316L stainless steels in $0.5 \mathrm{M} \mathrm{NaCl}$ after polarization treatments at $0.5 \mathrm{~V}$ for $30 \mathrm{~min}$ in $1 \mathrm{M} \mathrm{Na}_{2} \mathrm{SO}_{4}$ of $\mathrm{pH}$ 3. The value of current density in each curve with a label of $\mathrm{A}, \mathrm{B}$, or $\mathrm{C}$ is given by the ordinate scale with the corresponding label.

current spikes in the potential region between $E_{\mathrm{r}}$ and $E_{\mathrm{pit}}$. The distribution of each of these parameters was examined using a normal probability paper.

Figures 5, 6 and 7 show the normal probability plots of the distribution of $E_{\mathrm{r}}, E_{\mathrm{pit}}$, and $N_{\mathrm{msp}}$, respectively. Linear relationships were observed for the three parameters examined, suggesting that the scattering of data follows a normal distribution. The average value of $E_{\mathrm{r}}$, which is the value of $E_{\mathrm{r}}$ at the cumulative probability of $50 \%$, increased gradually with increasing treatment potential, while the slope of the normal probability plot, which corresponds to the reciprocal of standard deviation, remained unchanged. The average value of $E_{\text {pit }}$ increased significantly with increasing treatment potential and, at the same time, the slope of the normal probability plot became less steep. The latter result is due to the fact that very high $E_{\text {pit }}$ values above $1.0 \mathrm{~V}$ were obtained for several specimens treated at potentials higher than $0.2 \mathrm{~V}$. In other words, the scattering of $E_{\text {pit }}$ data originates not only from the intrinsic nature of the pitting process but also from the variation of the effectiveness of polarization treatments for eliminating pit initiation sites.

In Figure 7 the average value of $N_{\text {msp }}$ decreases remarkably with polarization treatment. The average value of $N_{\text {msp }}$ for specimens treated at potentials above $0.3 \mathrm{~V}$ is at least one order of magnitude lower than that for the as-polished specimen, indicating that the number of pit initiation sites decreased significantly with the polarization treatments employed in this study. The decrease in the number of pit initiation sites may well explain the observed increase in $E_{\text {pit }}$. However, there is also a possibility that the passivation effect, that is, the Cr enrichment in passive films, was induced by the polarization treatment and that this led to the improvement of pitting resistance.

To examine the passivation effect, the anodic polarization curves in $0.5 \mathrm{M} \mathrm{NaCl}$ were measured after the following nitric passivation treatment: the immersion of specimens in $30 \%$ $\mathrm{HNO}_{3}$ at $60^{\circ} \mathrm{C}$ for $1 \mathrm{~h}$. A typical result is shown in Figure 8

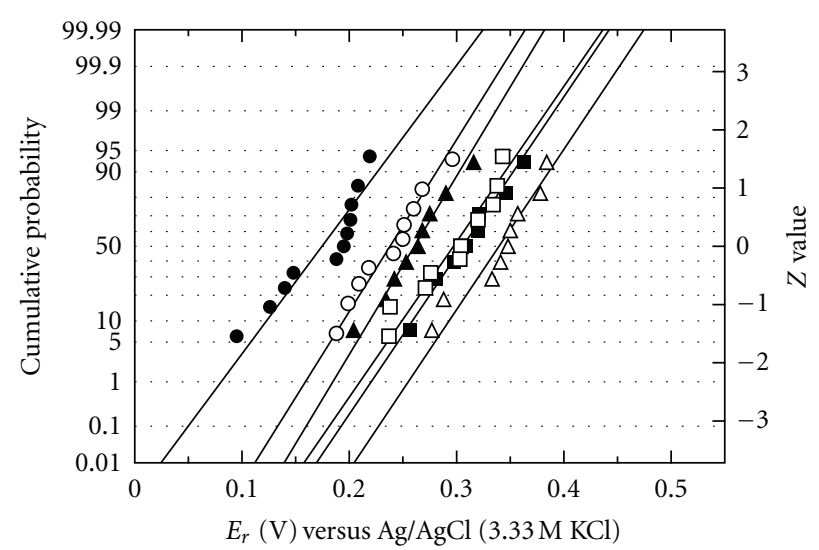

- As polished

O $0.1 \mathrm{~V}, 30 \mathrm{~min}$

A $0.2 \mathrm{~V}, 30 \mathrm{~min}$

$\triangle 0.3 \mathrm{~V}, 30 \mathrm{~min}$

- $0.4 \mathrm{~V}, 30 \mathrm{~min}$

$\square 0.5 \mathrm{~V}, 30 \mathrm{~min}$

FIGURE 5: Normal probability plots of onset potential of metastable pitting, $E_{\mathrm{r}}$, in $0.5 \mathrm{M} \mathrm{NaCl}$ for commercial Type $316 \mathrm{~L}$ stainless steels after polarization treatments at different potentials for $30 \mathrm{~min}$ in $1 \mathrm{M} \mathrm{Na}_{2} \mathrm{SO}_{4}$ of $\mathrm{pH} 3$.

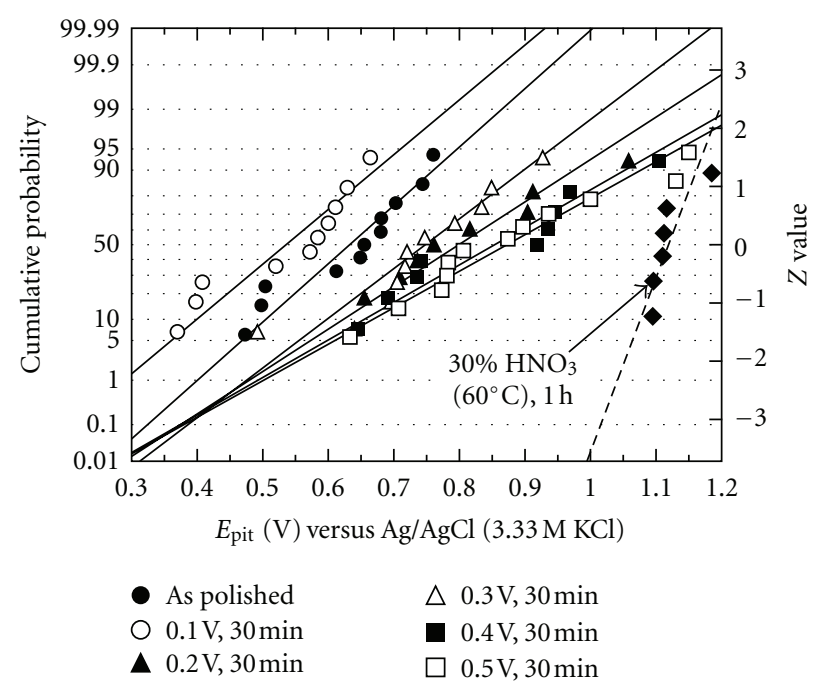

FIGURE 6: Normal probability plots of onset potential of stable pitting, $E_{\text {pit }}$, in $0.5 \mathrm{M} \mathrm{NaCl}$ for commercial Type $316 \mathrm{~L}$ stainless steels after polarization treatments at different potentials for $30 \mathrm{~min}$ in $1 \mathrm{M} \mathrm{Na}_{2} \mathrm{SO}_{4}$ of $\mathrm{pH}$ 3. The data for nitric acid passivation is shown for comparison.

and compared with another result after the polarization treatment at $0.5 \mathrm{~V}$. After the nitric acid passivation treatment, no metastable pitting was observed and stable pitting occurred only at a very high potential of about $1.1 \mathrm{~V}$ (see also Figure 6). Even though the pitting potential of the two specimens shown in Figure 8 is almost identical, the current densities in the passivity and transpassivity regions are quite different. The current density of the specimen passivated in nitric acid was extremely low in the passivity region but increased remarkably with potential in the transpassivity region above $0.6 \mathrm{~V}$. Such a large change in the current density 


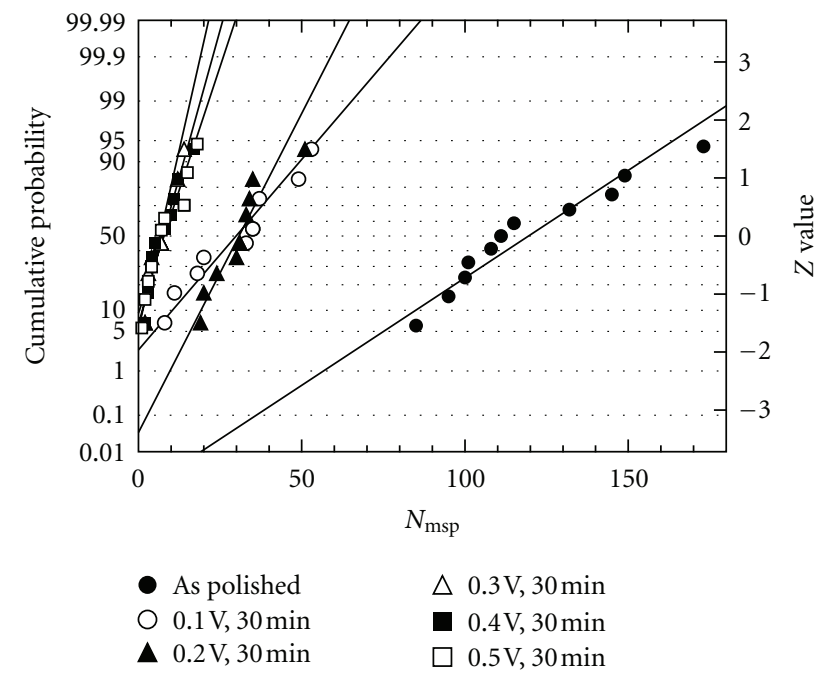

Figure 7: Normal probability plots of the number of metastable pits, $N_{\text {msp }}$, in $0.5 \mathrm{M} \mathrm{NaCl}$ for commercial Type $316 \mathrm{~L}$ stainless steels after polarization treatments at different potentials for $30 \mathrm{~min}$ in $1 \mathrm{M} \mathrm{Na}_{2} \mathrm{SO}_{4}$ of $\mathrm{pH} 3$.

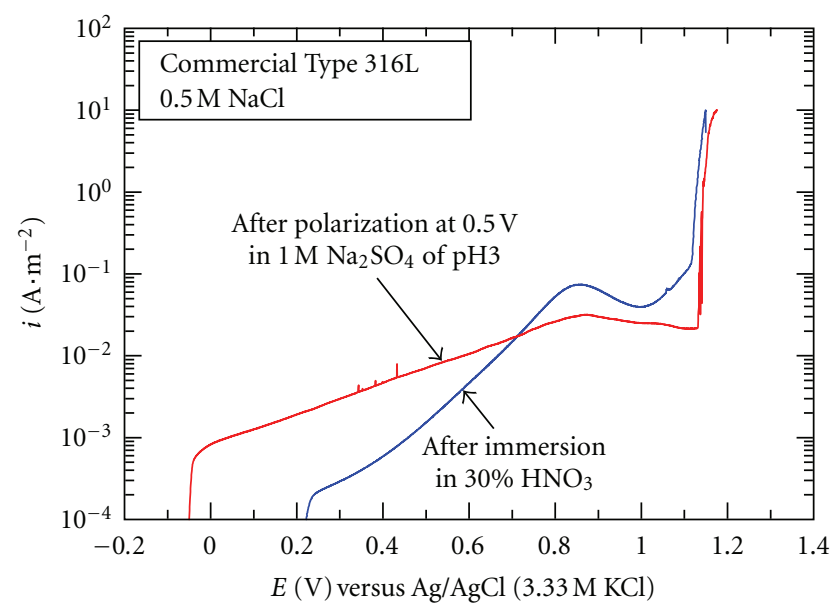

Figure 8: Anodic polarization curves in $0.5 \mathrm{M} \mathrm{NaCl}$ for commercial Type $316 \mathrm{~L}$ stainless steels after passivation for $1 \mathrm{~h}$ in $30 \% \mathrm{HNO}_{3}$ at $60^{\circ} \mathrm{C}$ and after polarization treatments at $0.5 \mathrm{~V}$ for $30 \mathrm{~min}$ in $1 \mathrm{M}$ $\mathrm{Na}_{2} \mathrm{SO}_{4}$ of $\mathrm{pH} 3$.

of the specimen passivated in nitric acid can be explained by the presence of a passive film enriched with $\mathrm{Cr}$ oxide. The presence of $\mathrm{Cr}$ oxide suppresses dissolution in the passive state but accelerates dissolution in the transpassive state to form soluble $\mathrm{Cr}(\mathrm{VI})$ species.

The passive current density at $0.3 \mathrm{~V}, i_{\text {pass }}$, in $0.5 \mathrm{M} \mathrm{NaCl}$ was read from all the polarization curves measured, and its average value was calculated and then plotted against the polarization treatment potential in Figure 9. While the average value of $i_{\text {pass }}$ decreased slightly with increasing treatment potential, it was always one order of magnitude higher than that for specimens passivated in nitric acid and was rather close to that for as-polished specimens. It is therefore suggested that the polarization treatment used in

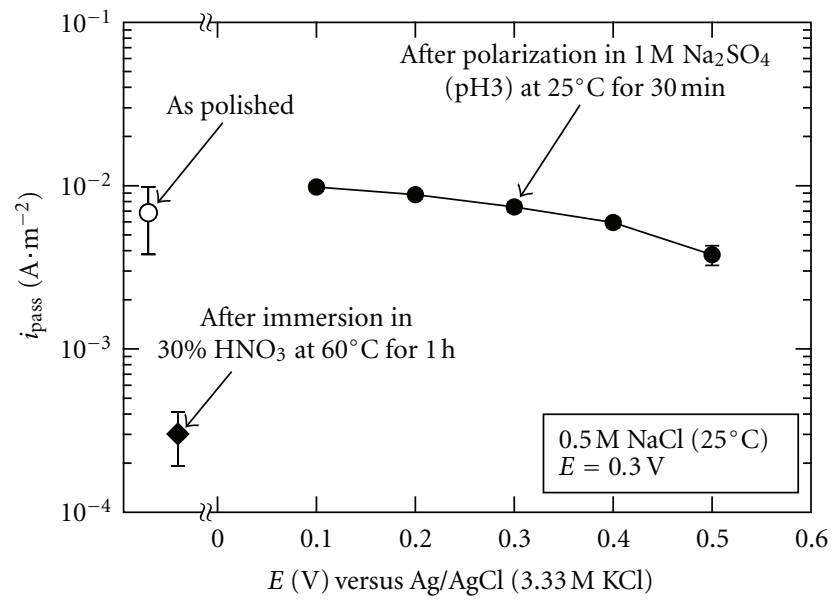

Figure 9: Passive current density, $i_{\text {pass }}$, at $0.3 \mathrm{~V}$ in $0.5 \mathrm{M} \mathrm{NaCl}$ as a function of polarization potential in $1 \mathrm{M} \mathrm{Na}_{2} \mathrm{SO}_{4}$ of $\mathrm{pH} 3$ for commercial Type 316L stainless steels. The corresponding data for as-polished and $\mathrm{HNO}_{3}$ passivated steels are shown for comparison. Error bars indicate a standard deviation of $i_{\text {pass }}$.

this study did not have a strong passivation effect but had the significant beneficial effect of reducing the number of pit initiation sites.

\section{Conclusions}

By comparing the anodic polarization curves in $0.5 \mathrm{M} \mathrm{NaCl}$ for high-purity Type 316L stainless steels with those of commercial 316L stainless steels, it is confirmed that the removal of $\mathrm{MnS}$ is essential to derive excellent pitting corrosion resistance. Manganese sulfide $(\mathrm{MnS})$ and some oxide $(\mathrm{CaO}$, $\mathrm{SiO}_{2}$ ) inclusions on the surface of commercial Type 316L stainless steels were dissolved by potentiostatic polarization treatments in $1 \mathrm{M} \mathrm{Na}_{2} \mathrm{SO}_{4}$ with $\mathrm{pH}$ 3. After polarization treatment, the number of current spikes due to metastable pitting decreased significantly and the pitting potential increased, while the passive current density did not change as remarkably as for specimens subjected to nitric passivation treatment. The elimination of pit initiation sites rather than the modification of the chemical composition of passive films is important to improve the pitting corrosion resistance of stainless steels.

\section{References}

[1] J. E. Castle and R. Ke, "Studies by auger spectroscopy of pit initiation at the site of inclusions in stainless steel," Corrosion Science, vol. 30, no. 4-5, pp. 409-428, 1990.

[2] M. A. Baker and J. E. Castle, "The initiation of pitting corrosion of stainless steels at oxide inclusions," Corrosion Science, vol. 33, no. 8, pp. 1295-1303, 1992.

[3] R. Ke and R. Alkire, "Surface analysis of corrosion pits initiated at MnS inclusions in 304 stainless steel," Journal of the Electrochemical Society, vol. 139, no. 6, pp. 1573-1580, 1992.

[4] M. A. Baker and J. E. Castle, "The initiation of pitting corrosion at MnS inclusions," Corrosion Science, vol. 34, no. 4, pp. 667-682, 1993. 
[5] R. Ke and R. Alkire, "Initiation of corrosion pits at inclusions on 304 stainless steel," Journal of the Electrochemical Society, vol. 142, no. 12, pp. 4056-4062, 1995.

[6] G. S. Frankel, "Pitting corrosion of metals: a review of the critical factors," Journal of the Electrochemical Society, vol. 145, no. 6, pp. 2186-2198, 1998.

[7] H. Krawiec, V. Vignal, O. Heintz, R. Oltra, and J. M. Olive, "Influence of the chemical dissolution of MnS inclusions on the electrochemical behavior of stainless steels," Journal of the Electrochemical Society, vol. 152, no. 7, pp. B213-B219, 2005.

[8] T. L. S. L. Wijesinghe and D. J. Blackwood, "Real time pit initiation studies on stainless steels: the effect of sulphide inclusions," Corrosion Science, vol. 49, no. 4, pp. 1755-1764, 2007.

[9] G. S. Eklund, "Initiation of pitting at sulfide inclusions in stainless steel," Journal of the Electrochemical Society, vol. 121, no. 4, pp. 467-473, 1974.

[10] G. Wranglén, "Pitting and sulphide inclusions in steel," Corrosion Science, vol. 14, no. 5, pp. 331-349, 1974.

[11] T. Suter, E. G. Webb, H. Böhni, and R. C. Alkire, "Pit initiation on stainless steels in $1 \mathrm{M} \mathrm{NaCl}$ with and without mechanical stress," Journal of the Electrochemical Society, vol. 148, no. 5, pp. B174-B185, 2001.

[12] C. Punckt, M. Bölscher, H. H. Rotermund et al., "Sudden onset of pitting corrosion on stainless steel as a critical phenomenon," Science, vol. 305, no. 5687, pp. 1133-1136, 2004.

[13] P. Schmuki, H. Hildebrand, A. Friedrich, and S. Virtanen, "The composition of the boundary region of MnS inclusions in stainless steel and its relevance in triggering pitting corrosion," Corrosion Science, vol. 47, no. 5, pp. 1239-1250, 2005.

[14] H. Krawiec, V. Vignal, O. Heintz, and R. Oltra, "Influence of the dissolution of $\mathrm{MnS}$ inclusions under free corrosion and potentiostatic conditions on the composition of passive films and the electrochemical behaviour of stainless steels," Electrochimica Acta, vol. 51, no. 16, pp. 3235-3243, 2006.

[15] I. Muto, Y. Izumiyama, and N. Hara, "Microelectrochemical measurements of dissolution of $\mathrm{MnS}$ inclusions and morphological observation of metastable and stable pitting on stainless steel," Journal of the Electrochemical Society, vol. 154, no. 8, pp. C439-C444, 2007.

[16] I. Muto, D. Ito, and N. Hara, "Microelectrochemical investigation on pit initiation at sulfide and oxide inclusions in type 304 stainless steel," Journal of the Electrochemical Society, vol. 156, no. 2, pp. C55-C61, 2009.

[17] S. J. Zheng, Y. J. Wang, B. Zhang, Y. L. Zhu, C. Liu, and P. Hu, "Identification of $\mathrm{MnCr}_{2} \mathrm{O}_{4}$ nano-octahedron in catalysing pitting corrosion of austenitic stainless steels," Acta Materialia, vol. 58, no. 15, pp. 5070-5085, 2010.

[18] J. S. Noh, N. J. Laycock, W. Gao, and D. B. Wells, "Effects of nitric acid passivation on the pitting resistance of 316 stainless steel," Corrosion Science, vol. 42, no. 12, pp. 2069-2084, 2000.

[19] R. R. Maller, "Passivation of stainless steel," Trends in Food Science and Technology, vol. 9, no. 1, pp. 28-32, 1998.

[20] J. Shinozaki, I. Muto, T. Omura, M. Numata, and N. Hara, "Local dissolution of MnS inclusion and microstructural distribution of absorbed hydrogen in carbon steel," Journal of the Electrochemical Society, vol. 158, no. 9, pp. C302-C309, 2011.

[21] T. Shibata and T. Takeyama, "Stochastic theory of pitting corrosion," Corrosion, vol. 33, no. 7, pp. 243-251, 1977.
[22] T. Shibata, "Stochastic studies of passivity breakdown," Corrosion Science, vol. 31, pp. 413-423, 1990.

[23] T. Shibata, "1996 W.R. Whitney Award Lecture: statistical and stochastic approaches to localized corrosion," Corrosion, vol. 52, no. 11, pp. 813-830, 1996. 

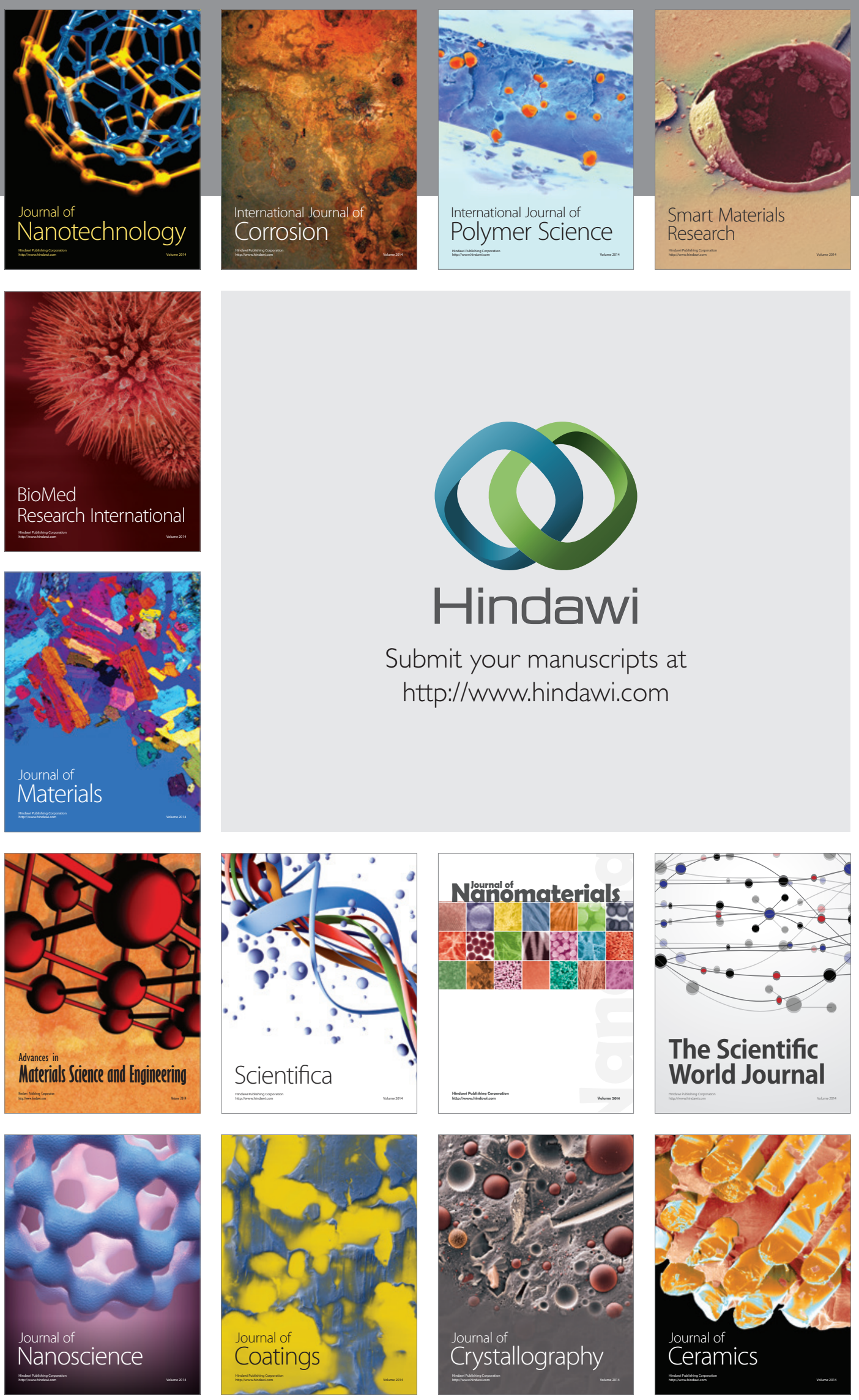

The Scientific World Journal

Submit your manuscripts at

http://www.hindawi.com

\section{World Journal}

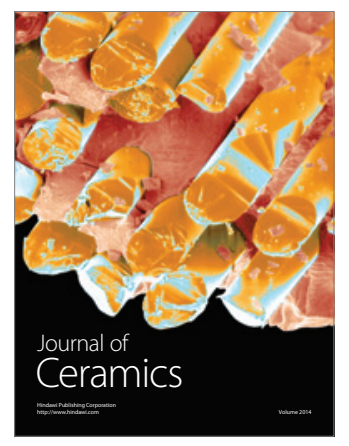

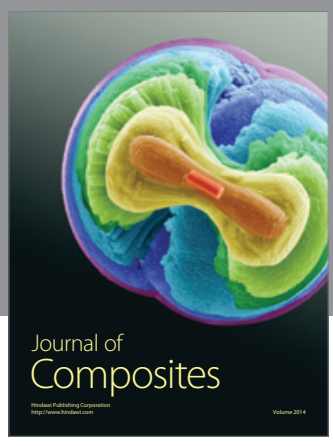
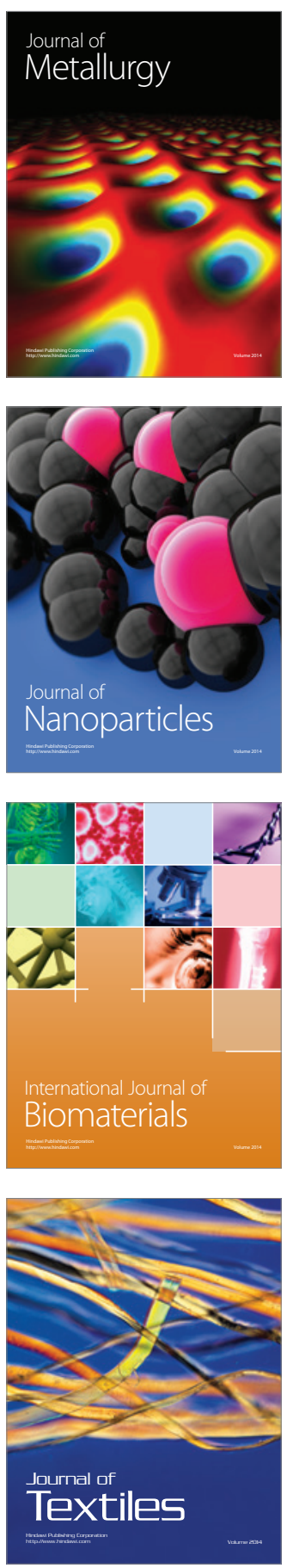